\title{
AUGUST RAUBER'S IDEAS FOR THE CREATION OF AN ANATOMY MUSEUM IN LITHUANIA (1920-1940)
}

\author{
Angelé Rudžianskaité, Anita Dabužinskienė, Lena Green, \\ VEGA KRIAUČIŪNIENE் \\ Museum of the History of Lithuanian Medicine and Pharmacy, \\ Lithuanian University of Health Sciences, Kaunas, Lithuania
}

\begin{abstract}
Professor August Rauber (1841-1917) created the most important school of anatomy in the Baltic region. His students continued his educational and research work in their native countries. One of them was Professor Jurgis Žilinskas (1885-1957) who laid the foundation to Lithuanian anatomy and anthropology. From 1906-1912, he studied medicine at the University of Yuryev (Tartu) where Prof. A. Rauber worked for 25 years as Head of the Institute of Anatomy. In 1890, A. Rauber opened the Anatomy Museum there. In the university, J. Žilinskas maintained close contacts with Professors A. Rauber (1841-1917), N. N. Burdenko (1876-1946), W. Zoege-Manteuffel (1857-1926) and E. Landau (1878-1959). After graduation from the university, J. Žilinskas as a talented student was invited to work as an assistant at the Department of Hospital Surgery at Yuryev University. After Lithuania restored its independence on 16 February 1918, Prof. J. Žilinskas participated actively in the organization of medical studies in Lithuania (1922-1940) and was one of the creators and the principal patron of the Museum of Anatomy. Returning to Lithuania, J. Žilinskas brought along the most advanced ideas of his professors, especially of his honoured Prof. A. Rauber. During this period, the collection of the museum increased to 3,890 specimens. Osteological specimens comprised 1,925 (around 50\%) of the specimens, wet specimens 753 (19.3\%), corrosion specimens - 467 (12\%), transparent specimens - 201 (5.2\%), dry specimens - 107 (2.8\%) and models - 437. Professor J. Žilinskas' collection constitutes $50 \%$ of the present exhibits at the Anatomy Museum of the Lithuanian University of Health Sciences.
\end{abstract}

Keywords: anatomy; museum; transparent specimen; corrosion specimen 


\section{J. ŽILINSKAS' ACTIVITIES IN ORGANIZATION OF THE LITHUANIAN UNIVERSITY IN KAUNAS}

The educational and research activities of J. Žilinskas have been evaluated by Professors Rimvydas Stropus [1], Selezijus Pavilonis, Gintautas Čèsnys [2] and other authors. This article is meant to discuss the organization and development of the Museum of Anatomy, founded by Professor J. Žilinskas at the Institute of Anatomy of the Lithuanian University in 1923.

J. Žilinskas took the vision of the Anatomy Museum from his teacher, Professor A. Rauber, who headed the Anatomy Department at the University of Yuryev (now Tartu) for 25 years (1885-1911). Professor Rauber took over the collection of anatomical specimens from his predecessors Ch. G. L. Stieda and E. O. Körber and opened the Museum of Anatomy in 1890 [3].

J. Žilinskas remained in contact with his teacher until his death. When A. Rauber was on his deathbed, J. Žilinskas, who was already working as an assistant in the Department of Hospital Surgery, visited him and offered his help, which the professor refused. He also refused the help of Rudolf Virchov. R. Virchov spoke about this to J. Žilinskas during his internship in Germany in 1920 [4].

Having restored its independence on 16 February 1918, the Republic of Lithuania planned to reopen Vilnius University, which had been closed by the Russian Tsarist government in 1832. On 5 December 1918, the State Council adopted the Statute of Vilnius University [5]. But in January 1919, the Bolsheviks, and, on 19 of April 1919, the Poles captured Vilnius and its surroundings. The capital of the Republic of Lithuania was moved to Kaunas. On 2 May 1919, the famous medical scientists M. Nasvytis, P. Žemgulys, J. Alekna, J. Žilinskas, J. Brundza, V. Ingelevičius, A. Janulionis founded the Kaunas Medical Society (KMS) [6], one of the main tasks of which was to prepare for the foundation of the Higher School in Kaunas [7]. The Medical Division of Higher Courses (HC) was established on 27 April 1919. The intern of the Military Hospital in Kaunas, surgeon J. Žilinskas, was elected to be secretary and Dr. M. Nasvytis - head of the Anatomy Division of HC [8]. J. Žilinskas was commissioned to prepare lectures on topographic anatomy and surgery. Officially, the Higher Courses were established on 27 January 1920. The opening ceremony took place on the premises of Aušros Gymnasium (now Maironio Gymnasium, Gimnazijos St. 3, Kaunas). On 29 January, the surgeon J. Žilinskas delivered his first lecture on human anatomy for the students of the Higher Courses. To illustrate the lecture, he brought a skeleton to the school, which made a great impression upon the students. This skeleton was prepared by 
himself in the Kaunas Military Hospital [9]. R. Stropus, Professor Emeritus of the Anatomy Institute at the Lithuanian University of Health Sciences recalls, "We, anatomists, mention this date as the birthday of anatomy in Kaunas" [10].

In 1920, the Ministry of Justice handed over to the Medical Department the abandoned wooden building of a children's shelter at Mickevičiaus Street 7. "When I was given a dilapidated house and didn't have the money to renovate it, I had to fix it up on my own. I cleaned everything myself, filled in the holes in the floor. With the help of the Military Hospital orderly, a preparator and students, we painted the floors and walls, and made benches, stools and tables to put the corpses on. [...] So, the first Lithuanian Anatomy Institute on Mickevičiaus Street 7 was born," Professor J. Žilinskas wrote in 1956 [11].

The Lecturers' Council of the Medical Department applied to the Ministry of Education for scholarships for J. Žilinskas and V. Lašas (1892-1966) to create opportunities for continuing their professional development abroad [12]. After receiving the scholarship in the summer of 1920, J. Žilinskas went to the University of Königsberg, later to the institutes of anthropology in Berlin and Munich and visited museums of anatomy. In Jena, he ordered glass containers for the storage of wet anatomical specimens. At the University of Halle, he expressed interest in the preparation of various anatomical specimens, and at the University of Leipzig he purchased textbooks for the production of transparent specimens and ordered the chemicals needed for the preparation of transparent specimens. He had an opportunity to acquaint himself with the latest methods of preparation of anatomic specimens.

In March 1921, J. Žilinskas resigned from the Military Hospital and moved to work in the Medical Division of HC [13]. From 3 June to the end of 1923, J. Žilinskas lectured on histology and embryology. From December 1923, Professor Eber Landau held the position of Head of the Department of Histology and Embryology of the Lithuanian University [14].

When the Lithuanian University was officially established on 16 of February 1922, Professor J. Žilinskas (Fig. 1) wrote: "I have received a letter from the Minister of Education - on 16 February 1922, I was appointed Associate Professor in the Institute of Anatomy and temporarily in the Institute of Histology and Embryology at the Faculty of Medicine" [15].

In 1923, a two-storey brick house was built next to the first building of the Institute of Anatomy with body preservation tanks in the basement and laboratories for the preparation of anatomical specimens and craniological research on the first and second floors. This building also houses the Anatomy Museum (Fig. 2). 


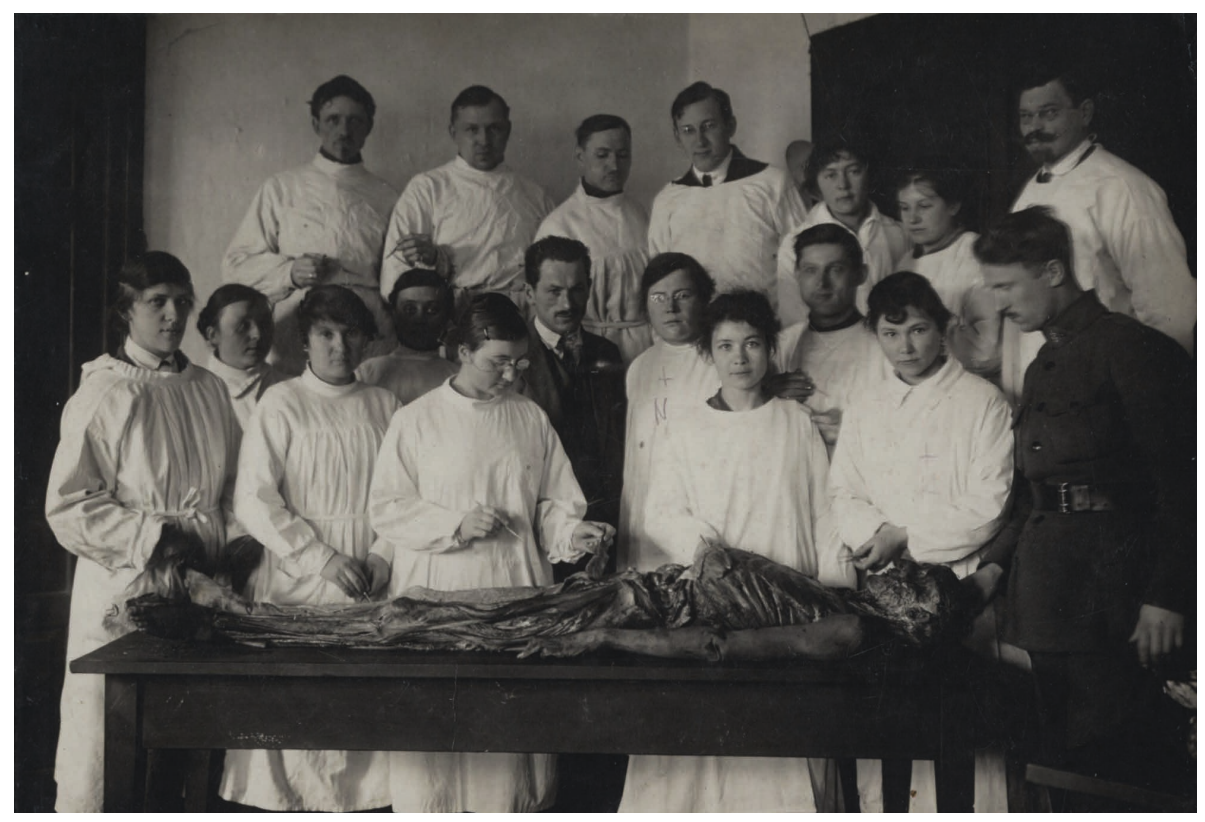

Figure 1. Professor Jurgis Žilinskas (centre) with students, circa 1933. (The archive of the Museum of History of Lithuanian Medicine and Pharmacy of the Lithuanian University of Health Sciences).

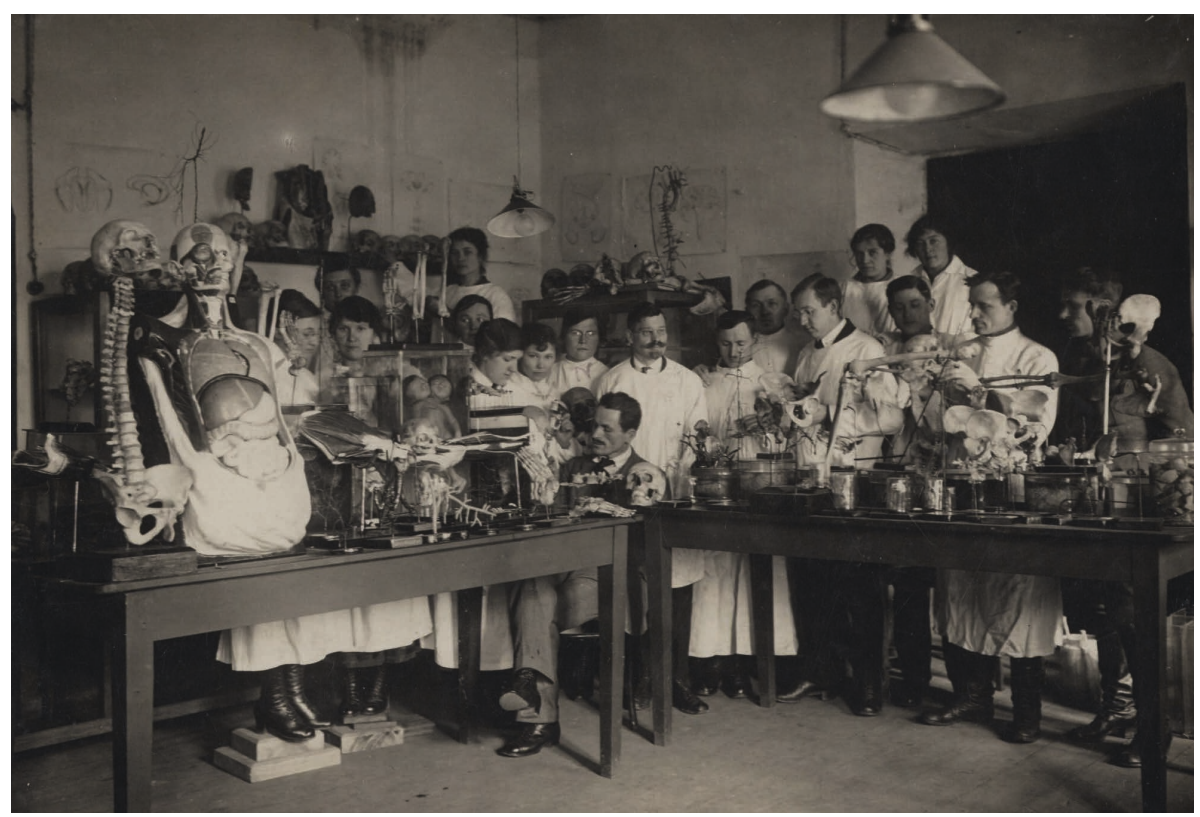

Figure 2. Professor Jurgis Žilinskas (sitting in the centre) in the Museum of Anatomy. (The archive of the Museum of History of Lithuanian Medicine and Pharmacy of the Lithuanian University of Health Sciences). 


\section{THE MUSEUM OF ANATOMY AND ITS SPECIMENS}

The course of acquisition and production of specimens and models by the Museum of Anatomy can be revealed by analysing the three available inventory books from 1922-1948. The journals indicate the date of purchase or manufacture of the specimens, the inventory number, the place of manufacture, the author, the price, and the date of write-off. Even today, many of the exhibits in this historic collection still have their authentic numbers. The most often used mass for making the models consisted of chalk powder, wax, glue, papiermâché and woollen fabric waste. Some of the models were made 5-10 times larger than the natural specimens. Already from the very first year activities of the Medical Division of High Courses, Professor J. Žilinskas had very skilful assistants - J. Bubėnaité, A. Aleknavičius, J. Tumaitè.

On 3 July 1931, the foundations of the new building of the Faculty of Medicine of Vytautas Magnus University were consecrated [16]. In 1933, the Faculty of Medicine was transferred to the present premises where, by the care of Professor, the Institute of Anatomy received plenty of room. The collection was placed in spacy big white glazed cabinets (Fig. 3). J. Žilinskas' student J. Dobrovolskaite-Tikniene writes: "For each of the professor's lectures, the material was carefully prepared, mainly drawings. They were redrawn from the six volumes of Rauber-Kopsch's Lehrbuch und Atlas der Anatomie des

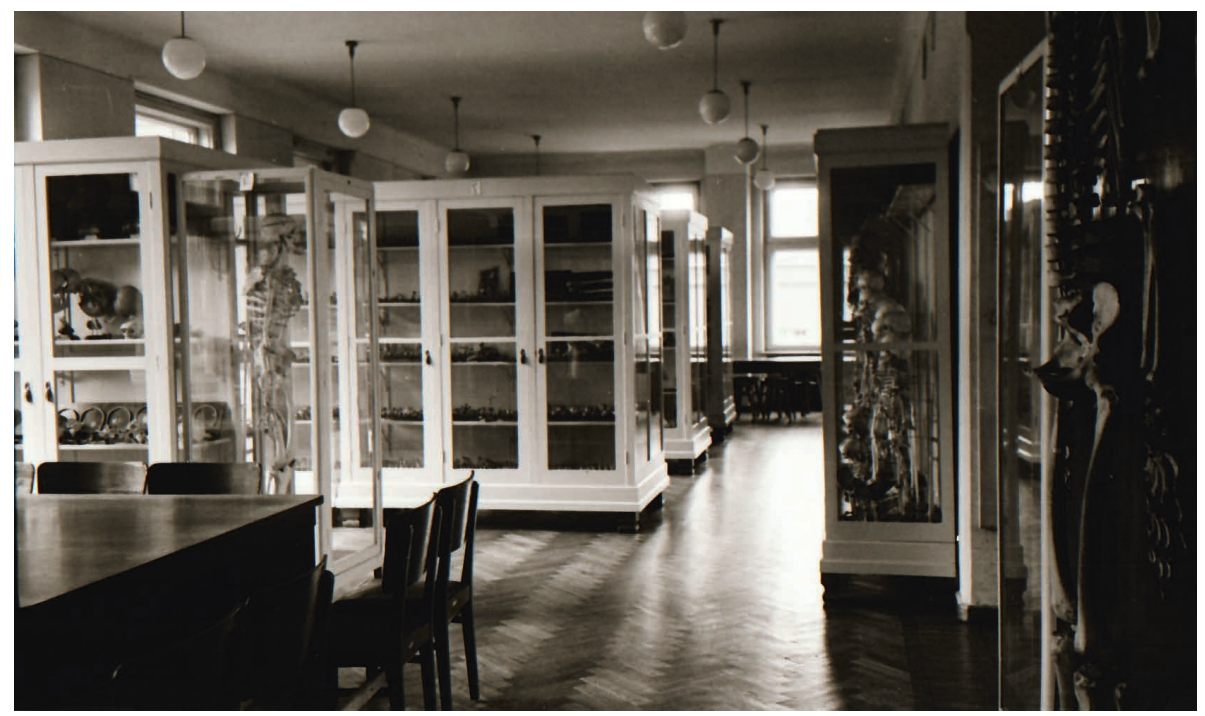

Figure 3. The Museum of Anatomy of the Kaunas Institute of Medicine. Photo by Andrius Rondomanskis, 1962. (The archive of Museum of History of Lithuanian Medicine and Pharmacy of the Lithuanian University of Health Sciences). 
Menschen, an atlas of human anatomy, because the professor liked and used this textbook. A. Rauber, a great anatomy expert, was held in great respect by the professor, and his portrait was displayed in J. Žilinskas' office" [17].

The exhibits of the Museum of Anatomy are classified according to the methods of their production.

\section{Osteological specimens}

This group includes skulls (1,090 specimens), separate bones or their sets (740 specimens) and skeletons (95 specimens). Bones have an essential role in anatomy teaching. They are indispensable for three-dimensional instruction in osteology as well as for understanding the sites of soft tissue insertion and the course of neurovascular structures in the region. Bone anatomy can most efficiently be learned by using dry bones in combination with textbooks and atlases as well as laboratory dissection [18]. In the laboratory of the Institute of Anatomy, the bone specimens were made in the classical way. For making those preparations a fat extractor was bought in 1922 and a Papin's digester in 1924. During the process of bones preparation, mechanical cleaning of soft tissue from the skeletal material, heating in Papin's digester (at less than $40^{\circ} \mathrm{C}$ ), fat extraction $(0.5 \% \mathrm{~K}(\mathrm{OH}))$ and bleaching in $3 \%$ hydrogen peroxide $\left(\mathrm{H}_{2} \mathrm{O}_{2}\right)$ solution were used.

From 1920-1933, the preparation of bone specimens became one of the main activities of the laboratory of the Institute of Anatomy, as six used cadavers remained after practical medical classes each semester. Professor had a very skilful laboratory assistant Vladimir Starostin (later associate professor of the Lithuanian Veterinary Academy) who started to work in the newly founded laboratory in 1926. V. Starostin learned to connect a set of bones to a common skeleton during his work in the laboratory of the Kunstkamera in St. Petersburg. The collection of adult skeletons encompassed 81 body frameworks, 20 of which had been made by V. Starostin. For studying the human skeletal development, 14 children's skeletons of different ages, human embryos and human foetuses were made in 1940.

In 1935, Professor together with students prepared several skeletons on which they made wire models of the nerves, blood vessels, and the lymphatic system. In the last specimen, the lymphatic system was modelled by the students A. Paprockas and L. Domijonaitis in accordance with the general view of the system presented in Rauber-Kopsch' anatomic atlases (Fig. 4). The most valuable exhibit of the museum - the skeleton of a gorilla - also belongs to the group of skeletal specimens. 


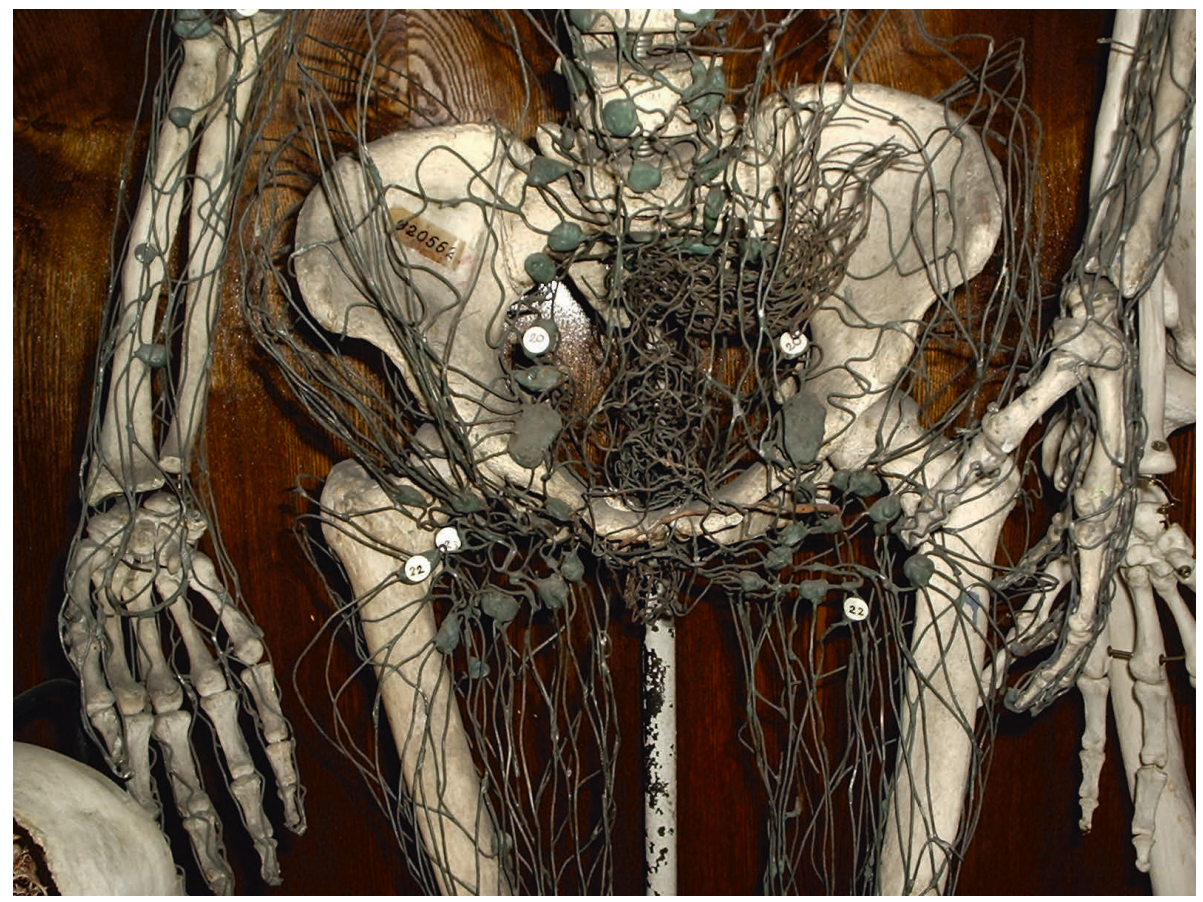

Figure 4. The model of the human lymphatic system, 1933. Photo by Angelè Rudžianskaite, 1995.

The collection of skulls was collected in various ways: 122 skulls were presented to the museum as gifts; about 300 were made in the laboratory; the rest were excavated and brought to the museum from various regions of Lithuania. In 1927-1929, nine skulls were assembled from separate cranial bones. The bones fastened to the metallic framework were excellent training appliances for the students undergoing the course of craniology.

\section{Wet specimens}

Professor called them fleshy specimens. 753 wet specimens were made by fixing them with formalin. As it may be seen from the aforementioned data, less attention was paid to the preparation of this group, as, during the training process, wet specimens are less accessible to the students. For storage and preservation of wet specimens, 1000 round and quadrangular glass jars had been bought in Germany during J. Žilinskas' internship in 1920.

The most interesting part among the specimens was a group of crosssections of the human body. In 1926 it was a very cold winter. Next to the 
building of the Institute of Anatomy, a human body had been frozen in a snowdrift for several months. Later, it was cut into $2-3 \mathrm{~cm}$ thick slices. Total number of such specimens was 130. In 1940, 26 cross-sections of a newborn were made. Accumulation of formalin-fixed specimens of the human brain was commenced in 1935. The total number of extracted and fixed brains was 262 . The specimens were used in the research work of the Institute of Anatomy. At this time, specimens of congenitally malformed newborns were also prepared: four Siamese twins, one anencephalus, a newborn with placenta and umbilical cord wound round the neck, and a newborn with osteomalacia.

\section{Corrosion specimens}

In 1925, Jāzeps Polikevičs (1891-1938), preparator of the Institute of Anatomy and Histology of the University of Latvia (Fig. 5), made the first corrosion specimens for the Lithuanian University. He was invited by J. Žilinskas. These two famous men were linked by a common noble purpose - to work for the sake of their native land and science. Preparator J. Polikevičs studied the preparation of corrosion and dry specimens in Germany. He not only made the first corrosion specimens for the Museum of Anatomy but also taught this technology to the laboratory staff. Under a contract (account No 1/102, 1/103, 1925), he made 88 corrosion specimens, the value of which amounted to 4825 Litas (\$1204) at that time. The preparations made by J. Polikevičs are notable for the properties of the injected material and their original design. We divided them into the following groups: the blood vessels of the human embryo, the heart

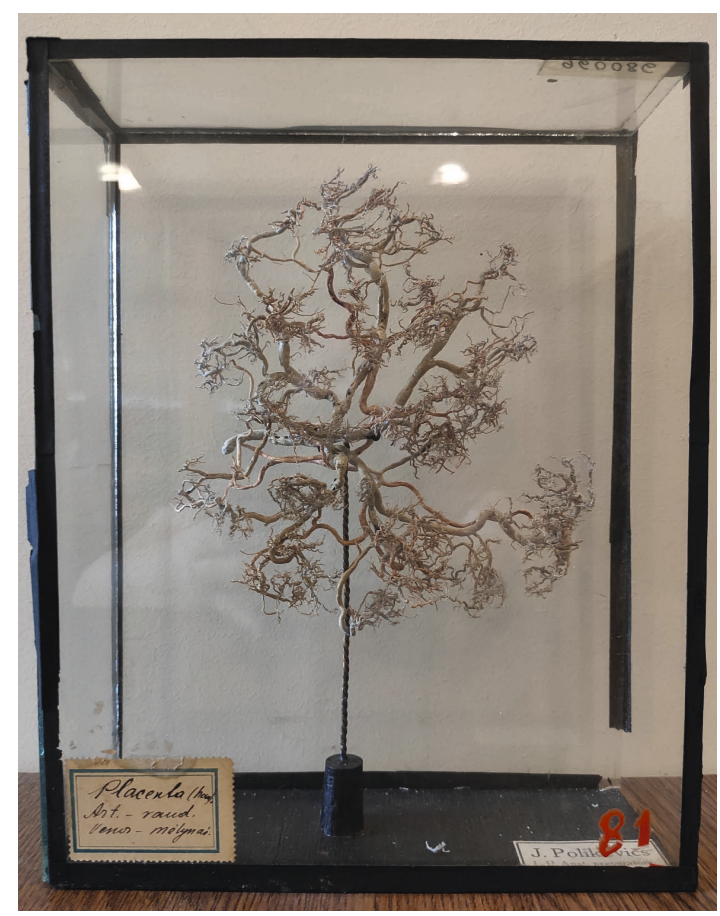

Figure 5. The corrosion specimen of human placenta made by preparator J Polikevičs, 1925. Photo by Vega Kriaučiūnienè, 2021. 
and the largest blood vessels, the hepatic blood vessels, the renal blood vessels and ureter, the blood vessels of the lung, the blood vessels of the spleen, the blood vessels of the sexual system and the sexual ducts, the inner ear [19]. The substance for filling of hollow organs or structures with a syringe had been made of plastic product waste dissolved in acetone. During the injection, the organ was immersed in water. The surrounding tissues were removed from the corrosion specimens slowly; the best specimens were made by putrefying. Lowconcentration hydrochloric acid was also used for this purpose.

\section{Models}

Models were the first specimens made in the newly established laboratory of the Medical Division of the Higher Courses. During the operation of the Higher Courses in 1920-1922, 79 models were made, later - 358. Special attention was paid to making enlarged models. They were necessary and useful for teaching the smaller parts of the body. There were models which showed the histological structure of tissues and organs: the structure of the intestinal villus, the tissues of the tongue (Fig. 6), the structure of the pilus and others. J. Žilinskas' student Associate Professor J. Dobrovolskaité-Tiknienè (1912-2003) has described how the laboratory assistants introduced a ten times magnified model of the human brain to the audience before the lecture. Once, during the break, the students accidentally knocked it down and smashed it. Two exhibition boards - the lymphatic system and the autonomic nervous system - were made of clay in 1933. There is an impressive $45 \mathrm{~cm}$ large model of the Corti organ of the inner ear. This specimen was carved of wood. The most

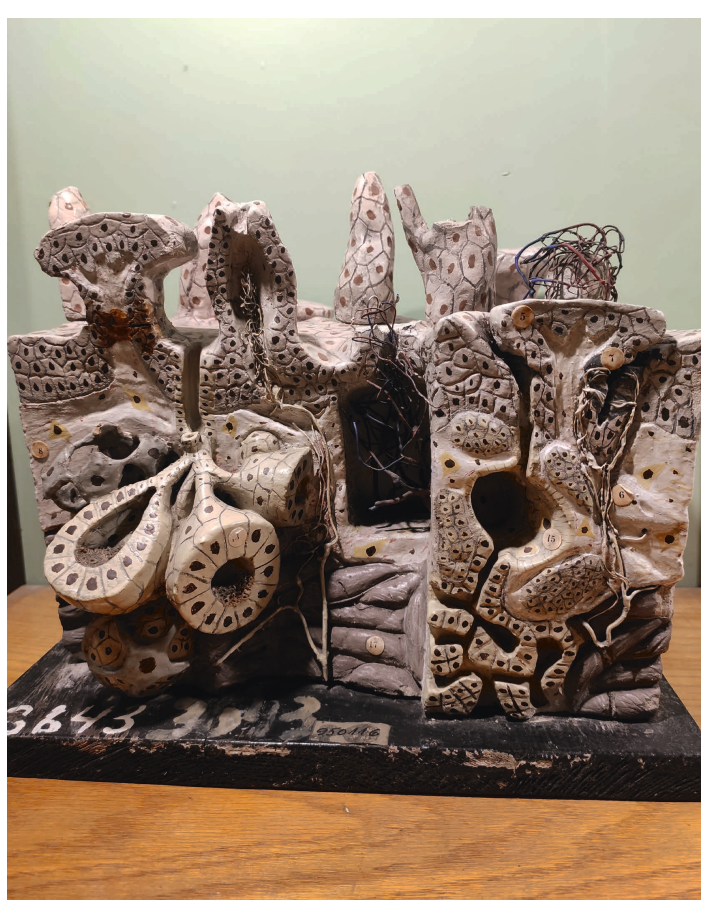

Figure 6. The histological model of the tongue structure, 1933. Photo by Vega Kriaučiūnienè, 2021. 
often used mass for making the models consisted of chalk powder, wax, wires, papier-mâché, glue, wood and woollen fabric waste. Unfortunately, most of the models were spoiled during a disastrous flood in 1946, as they had been hidden in the basement of the Faculty of Medicine during the Second World War.

\section{Dry (dried) specimens}

We attribute to this group of the specimens made of various parts of the body and its organs: 3 mummies, 69 dried lungs inflated with air, 4 parts of the digestive tract. In 1930, full mummies of a man and a woman were made. We can call them mummies with some reservation, as several preparation methods were used during their making. After separation of the skin and removal of the subcutaneous layer of adipose tissue, the intestines were inflated with air and dried; the main blood vessels were injected with gypsum. The first specimens of dried lungs inflated with air were made in 1925 year by preparator J. Polikevičs. By this method, a newborn who had been respirating and of a neonate who had not been respirating and several specimens of lungs of adult individuals with anthracosis were prepared. The most impressive among the latter were the quite blackened lungs of a 60 -year-old man with pneumonic melanosis. All these specimens were deposited in hermetically sealed glass boxes.

\section{Transparent specimens}

For the first time, Professor Žilinskas had seen the transparent specimens made by W. Spaltenholz during his training in Dresden 1920 (the German Hygiene Museum still keeps numerous Spalteholz's transparent specimens). In 1930, the first three transparent preparations were bought: a transparent temporal bone (Fig. 7), an intestinal loop with blood vessels injected with coloured latex and a human embryo at two months. In 1932, 14 additional transparent specimens were bought. All the other transparent specimens were made in the laboratory of the Institute of Anatomy. Preparator Ida Kronikaite mastered the difficult method of making such specimens in 1933 and made 19 of them. This skilful preparator also acquired the method of injecting blood vessels; therefore, the vessels are distinctly seen. 


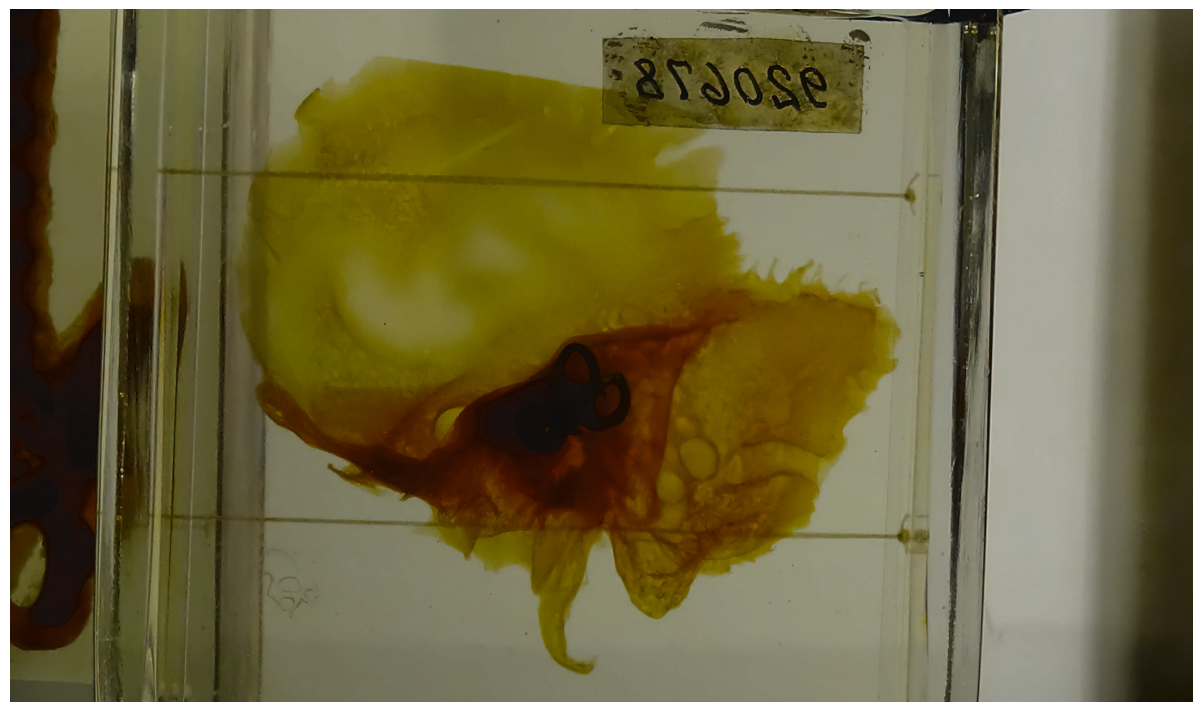

Figure 7. A transparent temporal bone, bought in Germany, 1930. Photo by Angele Rudžianskaitè, 1995.

\section{EXPANSION OF THE COLLECTION OF THE ANATOMY MUSEUM FROM 1920 TO 1940}

During the years of activity of the Higher Courses (1920-1922), a collection of 546 anatomical specimens was accumulated: 79 anatomical models and 467 bone specimens. From 1922-1940, the collection of the Anatomy Museum of Vytautas Magnus University increased to 3,890 specimens (the total number of items in the inventory books of the department was 5,800) with a value of 500,000 Litas $(\$ 125,000)$. Osteological preparations comprised 1,925 (around $50 \%)$ of the specimens, wet specimens - $753(19.3 \%)$, corrosion specimens 467 (12\%), transparent specimens - 201 (5.2\%), dry specimens - $107(2.8 \%)$ and models - 437. Professor J. Žilinskas' collection constitutes $50 \%$ of the present exhibition of the Anatomy Museum of the Lithuanian University of Health Sciences.

\section{PROF J. ŽILINSKAS' LEGACY}

We remember Professor J. Žilinskas with great respect, not only as a doctor, anatomist and anthropologist but also as an active public figure, a Lithuanian patriot. He contributed greatly to the founding of the Kaunas Medical Society, the Higher Courses, and the University of Lithuania. In the interwar 
period, the Museum of the Institute of Anatomy of the Faculty of Medicine was visited by many people. Reviews were written by a medical scientist from France, Swedish journalists, a professor from Estonia, Lithuanian doctors from America. In 1940, part of the assets of the Institute of Anatomy of the Faculty of Medicine at Vytautas Magnus University were moved to Vilnius University, but the collection of the Anatomy Museum remained in Kaunas. Professor J. Žilinskas also went to work at Vilnius University. In 1940, Professor Artūras Jurgutis (1909-1967) was appointed head of the Institute of Anatomy. Professor Jonas Nainys (1923-1989), who headed the Department of Forensic Anatomy from 1971 to 1980, and Professor R. Stropus contributed significantly to the preservation of the Anatomy Museum. In 1976, the museum was reconstructed to accommodate it for students' practical classes (Fig. 8).

Having created a school of Lithuanian anatomists and an excellent museum, Professor J. Žilinskas had emigrate to the United States of America in 1946. It fell to his lot to abandon the work of all his life. He died in 1957 as unemployed, having failed to find an opportunity to continue his research. Recalling Professor Jurgis Žilinskas, R. Stropus wrote: “The Museum of Human Anatomy, which was initiated by the efforts of his students and the later generation of anatomists, under the care of his students, and continuously replenished with new exhibits, has become a significant monument to the work started by Professor J. Žilinskas" [20].

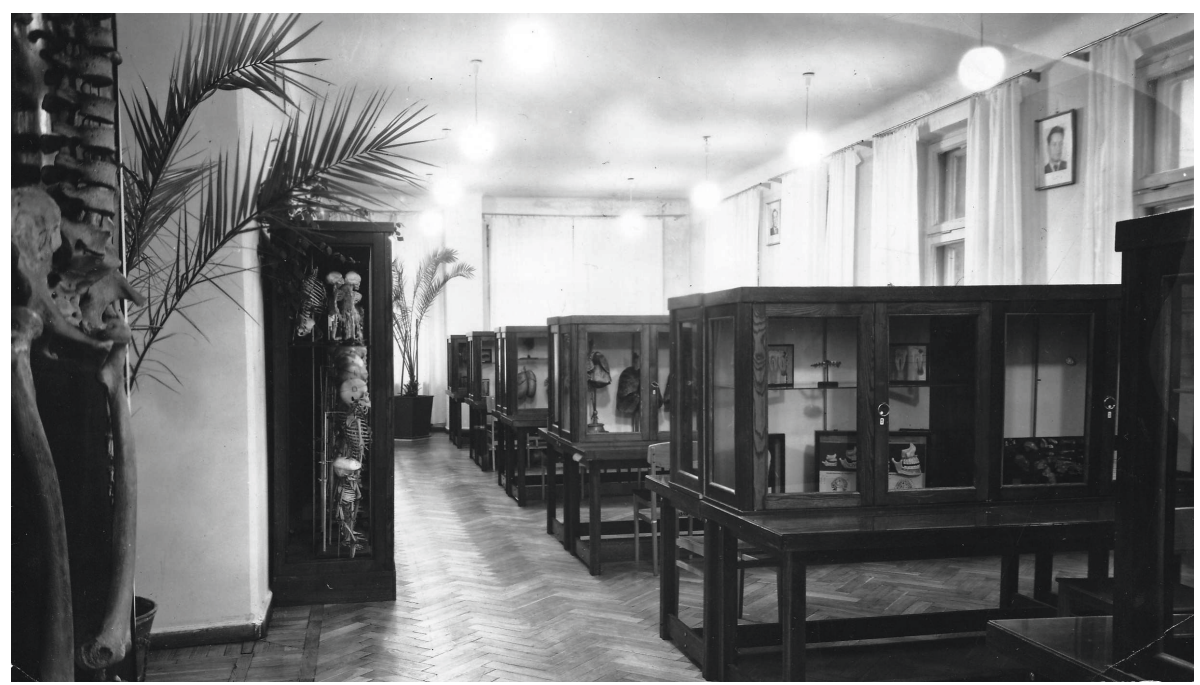

Figure 8. The Anatomy Museum of the Kaunas Institute of Medicine. Photo by Andrius Rondomanskis, 1975. (The archive of the Museum of History of Lithuanian Medicine and Pharmacy, the Lithuanian University of Health Sciences). 
In 1956, the Society of Lithuanian Physicians in America commissioned Professor J. Žilinskas to write his memoirs, the manuscript of which, thanks to Dr. Ramūnas Kondrotas, reached Kaunas in 2000. By the mediation of Angele Rudžianskaitè, former head of the Anatomy Museum (1990-1996) and the Lithuanian National Museum, J. Žilinskas' memoirs reached the readers in 2005.

\section{REFERENCES}

1. Stropus R. (2005). Profesorius Jurgis Žilinskas - lietuviškos anatomijos ir antropologijos kūrejjas. In: Jurgis Žilinskas. Atsiminimai. Lietuvos nacionalinis muziejus, Vilnius. 335-338.

2. Čèsnys G. (2005). Profesorius Jurgis Žilinskas. In: Jurgis Žilinskas. Atsiminimai. Lietuvos nacionalinis muziejus. Vilnius. 340-341.

3. Kasmel J., Kasmel T. (2010). On the collection of anatomical specimens at the Institute of Anatomy of the University of Tartu (the former Imperial University of Dorpat) from 1876-1886. In: Historia Scientiarum Baltica. Tallinn. 42.

4. Žilinskas J. (2005). Atsiminimai. Lietuvos nacionalinis muziejus, Vilnius. 201.

5. Janužytė A. (2013). Nacionaliniai ir tarptautiniai aukštojo mokslo ir studijų interesai pirmosios Lietuvos respublikos laikotarpiu. In: Socialinių mokslų studijos. 5 (2). 450.

6. Staugaitis J. (1929). Kauno Medicinos Draugijos 10 metų veikimas ir reikšmè. In: Medicina. 11. 828.

7. Siudikas V. (1997). Aukštosios medicinos studijos ir mokslas Kaune. Kauno medicinos akademija. 4.

8. Kronika. (1920). In: Medicina. Kaunas. 1. 32.

9. Kronika. (1921). In: Medicina. Kaunas. 6. 189.

10. Stropus R. (2005). Profesorius Jurgis Žilinskas - lietuviškos anatomijos ir antropologijos kūrëjas. In: Jurgis Žilinskas. Atsiminimai. Lietuvos nacionalinis muziejus, Vilnius. 335.

11. Žilinskas J. (2005). Atsiminimai. Lietuvos nacionalinis muziejus, Vilnius. 192.

12. Žilinskas J. (2005). Atsiminimai. Vilnius. 189.

13. Kronika. (1921) In: Medicina. Kaunas. 1. 32.

14. Vitkus A. (2009). In: Mokslas ir gyvenimas. 1. 15.

15. Žilinskas J. (2005). Atsiminimai. Lietuvos nacionalinis muziejus, Vilnius. 192.

16. Aukštasis medicinos mokslas. (1931). In: Medicina. Kaunas. 1. 370.

17. Dobrovolskaitė-Tiknienė J. (2005). Profesorius Jurgis Žilinskas. In: Jurgis Žilinskas Atsiminimai. Vilnius. 333.

18. Alayi et al. (2016). A review of bone preparation techniques for anatomical studies. Malaya Journal of Biosciences, 3 (2). 76. 
19. Rudžianskaite A., Dabužinskienè A. (2000). Corrosion preparations of preparator Jozef Polikevičs in Kaunas Medical University. In: Museum Anatomias Jacobi Primani - 80. Riga. 22.

20. Stropus R. (2005). Profesorius Jurgis Žilinskas - lietuviškos anatomijos ir antropologijos kūrëjas. In: Jurgis Žilinskas. Atsiminimai. Lietuvos nacionalinis muziejus, Vilnius. 338.

\section{Address for correspondence:}

Angelè Rudžianskaitė

Museum of the History of Lithuanian Medicine and Pharmacy

Lithuanian University of Health Sciences

Sukilèlių St. 76-8, Kaunas, LT 49 336, Lithuania

E-mail: angelrud@gmail.com 